\title{
How Do Javaneesee Employees Perceive About Their Job ? : \\ A Study of Javanese Employees Work Value
}

\author{
Siti Nuzulia ${ }^{1}$
}

\section{ABSTRACT}

Work value refers to an individual's perception about work and relates to the meaning an individual assign to work. The brilliance of an organization very much depends on an individual's work value, as work value affects organizational behavior, performance, productivity, and organizational commitment. Work value also has its foundation on the cultural background that someone is exposed to, as different cultural values/norms have different influence on an individual's cognition, emotion, motivation, and behavior. Therefore, a crosscultural study that compares relationships between work attitude and aptitude at various cultural levels is required.

This research is aimed at finding out the definitions work values hold by Javanese employees, because Javanese is one of the ethnics in Indonesia with its unique and typical custom. This research uses Indigenous Psychology. The participants were 700 employees of Javanese descent. The sampling method used was snowball sampling, in which the researcher randomly sample respondents that met the criteria, and they were then given the questionnaires.

Research findings suggest that respondents define work as activities to fulfill family welfare, do something meaningful, carry out religious teaching, apply knowledge and add new insight. The research found seven main Javanese work values, which are discipline, loyalty, honesty, responsibility, totality, good relationship with co-workers, and enthusiasm. Furthermore, the results showed that the most attainable values through working are keeping busy, gaining status and gaining freedom.

Keywords: work values, Javanese, employees

Value is an important variable to comprehend someone. Understanding value is crucial since it reflects belief for behaving and determining standard of life. Value is related to the way someone makes perception around. Furthermore, value influences someone's attitude, motivation

${ }^{1}$ Lecturer, Department of Psychology, Faculty of Education, Semarang State University. Gedung A1. 2nd Floor Jl. Raya Sekaran Gunungpati, Semarang, Jawa Tengah, Indonesia 


\section{How Do Javaneesee Employees Perceive About Their Job ? : A Study of Javanese Employees Work Value}

-and behavior. Prior research indicates that value is strong motivational forces which influence someone’s behavior (Meglino \& Ravlin, 1998). Thus, value explains someone’s choice about what the right or wrong is and what he likes or dislikes.

Various research has defined value since 1970's. An early definition by Rokeach (1973), states that value is enduring belief that a specific mode of conduct or end-state of existence is personally or socially preferable to an opposite or converse mode of conduct or end state of existence. Rokeach divides value in two types, instrumental and terminal value. Instrumental value relates to the preferable modes of conduct, on the other hand terminal value has relationship with preferable end-states. In addition Rokeach states that individual value system has two value types (instrumental and terminal). Every person has two different preferences on terminal or instrumental value.

Another research about value was developed based on previous research by Milton Rokeach. Zedeck (1997) defines work values as goals that people strive to attain by working. Similar to Zedeck, Super (1973) defines work value as someone objective that will be attained to satisfy him/her. Work value is the quality needed by employee from the job (Abboushi, 1990). It means that work values reflect the relationship between need and satistaction (Abboushi, 1990). Furthermore, work value can be defined as a quality needed by someone toward the job (BenShem \& Avi-Itzhak, 1991). Dose (1997) make definition about work value as a standard to evaluate the job to be right or wrong. In conclusion, value has two dimensions which are moral dimension (someone will consider something as right or wrong, and desire dimension (someone will consider something to be liked more than other things).

In organizational context, work value has significant implication for explaining the way someone behaves. Many previous research has rationalized the influence of work value on work behavior with the result showing that behavior is a manifestation of value. Smith's work (1949) already formulated that value is a determinant of work attitude, whereas attitude is work behavior predisposition. In addition, work value is able to predict employee responsibility, pride, and seriousness toward the job (Sulastiana, 2008). If someone is unable to meet his/her work value through the job, he/she may experience job dissatisfaction (Mitra, Jenkins \& Gupta, 1992). It means that work value could be used to explain differences in someone's performance and to predict job satisfaction (Hoppe, 1990).

To add, work value has significant role on determining job commitment (Meiyanto \& Santhoso, 1999), developing a commited workforce ( $\mathrm{Li}, 2008$ ) and preparing organization to be able to function well during periods of change ( $\mathrm{Li}, 2008)$. By understanding employee work value, organization will be easier to get through negotiation (Graham, Mintu \& Rodgers, 1994), to assist in developing reward systems (Kim, Park \& Suzuki, 1990), affect leadership and management style (Hoppe, 1993) and to facilitate communication (Varner \& Beamer, 1995). 


\section{How Do Javaneesee Employees Perceive About Their Job ? : A Study of Javanese Employees Work Value}

\section{Work Value and Culture}

Work value and cultural background can’t be separated. Hofstede (1980) clearly describes many variations of work value from different cultures. Furthermore, Ronen and Shenkar (1985) found that work value is significantly and consistently different from one culture to another.

Nowadays, organizations in Indonesia still adopt research result or theories from west countries especially USA. Meanwhile, many cross cultural research about work value is limited to replicate theory which exist today, for instance Maslow, Herzberg and McClleland theory (Hoppe, 1990). Whereas, previous research (Hofstede, 1980; Hope, 1990) conclude that theories made from west country (which have individual value) have limitation to explain the phenomenon in other countries specifically in Indonesia which has collectivism value.

Referring to the argument of Markus and Kitayama (1991) who rebut the notion that western theory can be generalized to other cultures as well, there is the need for a cross-cultural research that compares relationships among work attitude at certain levels of different cultures in many nations. Markus and Kitayama based their argument on the fact that cultural values influence individual cognitive, emotion, motivation, and behavior.

Some researchers argue that certain cultures influence work attitude as different nations promote different set of cultures (Hoftstede, 1980; Woo, 2009). According to Hofstede (1980), people take situations differently because they are conditioned by different education and life experience shaped in their separate cultures. Therefore, an individual's cultural background plays an important role in shaping his/her attitude and behavior. Hofstede also defines culture as a collective programming on how to think, act, and behave that result in different aspects in a person's life that include belief, attitude, and behavior. This means that culture nurtures an individual's belief, attitude, and behavior in a special in the process of collective learning. It is clearly seen that culture must have special attention especially when we make a research about value.

Based on the explanation before about the urgensi of understanding work value in cultural context, this research try to explore Javanese employees work value. Javanese employees are chosen because Javanese is the largest ethnic in Indonesia which have unique characteristic. Javanese life has a form of community. Among the community of kinship, mutual cooperation and divinity (Herusatoto, 2003). Living together implement mutual assistance, is typical of the family. Java community is not a fellowship of individuals, but one unified form of "one for all and all for one" (Herusatoto, 2003). Moreover, according to the Herusatoto (2003) Javanese attitude to life has character and commendable behavior is called "rila" or willing, "narima" or accept the fate he received, friends or loyal to the promise, patiently or field chest, and "Budi luhur" or have a good mind. 


\section{METHOD}

This research uses indigenous psychology approach. Indigenous psychology is an approach that stresses on studying the way people act and think within their cultural context. (Kim and Berry, 1993)

\section{Participant}

The participants are 700 Javanese employees in Java. The criterion for 'employee' is people working for private or national corporations in Java.

\section{Data Collection}

The tool used to collect data in this research is open-ended questionnaires and value scale. The sampling technique used is the snowball sampling method in which the researcher contacted qualified volunteer samples and asked them to recommend a colleague, relative, or acquaintance that they deem suit the criteria of a respondent the researcher needs. The followings are questions respondents were subject to:

Table 1. The List of Unit Analysis

\begin{tabular}{|c|c|c|}
\hline Unit analysis & Sub unit analysis & The tools used \\
\hline \multirow{4}{*}{ Work Value } & The definition of work value & Open-ended questionnaire \\
\cline { 2 - 3 } & Factors affecting someone & Open-ended questionnaire \\
\cline { 2 - 3 } & working & Open-ended questionnaire \\
\cline { 2 - 3 } & Work value & $\begin{array}{c}\text { Value Scale (adapted from } \\
\text { Ucanok, 2008) }\end{array}$ \\
\hline
\end{tabular}

\section{Data Analysis}

The data collected using the open-ended questionnaire are analyzed with indigenous psychology approach (Primasari and Yuniarti 2012). The stages include preliminary coding, categorization, axial coding, and cross-tabulating (Primasari and Yuniarti 2012). Preliminary coding is conducted by selecting responses according to their similarities. Similarities are not determined by the researcher's interpretation but exactly what the respondents say during the survey. Initial axial coding is identifying and making the researcher familiar with response from participants. Axial coding is carried out by combing similar answers and then they are coded and categorized. Coding is made many times as response diversity requires. Cross-tabulation is then made to show the many responses of existing groups. These analyses are conducted by dividing questions into categories based on a frequency table. 


\section{RESULT}

\section{Definitions of work}

Javanese employees define work in seven concept. They define work as activities to fulfill family welfare, do something meaningful, carry out religious teaching, gain self actualization, apply knowledge, and to add new insigt. Table 1 describes the result.

Table 2 : Definition of work

\begin{tabular}{|l|c|}
\hline \multicolumn{1}{|c|}{ Definition of work } & Percentage \\
\hline Work is activities to fulfill family welfare & $52.23 \%$ \\
Work is activities to do something meaningful & $16.96 \%$ \\
Work is activities to carry out religious teaching & $12.20 \%$ \\
Work is activities to gain self actualization & $7.75 \%$ \\
Work is activities to apply knowledge & $6.10 \%$ \\
Work is activities to add new insight & $4.76 \%$ \\
\hline
\end{tabular}

\section{Factors affecting someone working}

Table 2 shows the factors affecting someone working. The main reasons are to maximize their life, success and fulfill welfare.

Tabel 3. Factors affecting someone working?

\begin{tabular}{|l|c|}
\hline \multicolumn{1}{|c|}{ Factors affecting someone working } & Procentage \\
\hline To gain life satisfaction & 48.49 \\
As a key of success & 43.96 \\
To fulfill daily needs & 7.55 \\
\hline
\end{tabular}

\section{Work Value}

Tabel 4 shows respondents values of work. The values are discipline, loyalty, honesty, responsibility, totality, good relationship with co-workers, and enthusiasm.

Tabel 4. Values of work

\begin{tabular}{|l|c|}
\hline \multicolumn{1}{|c|}{ Value } & Procentage \\
\hline Discipline & 16.79 \\
Loyalty & 16.73 \\
Honesty & 16.62 \\
Responsibility & 16.32 \\
Totality & 14.53 \\
Good relationship with co-workers & 11.56 \\
Enthusiasm & 7.43 \\
\hline
\end{tabular}




\section{Attainable values through working}

Table 4 describes the attainable values through working. It is divided into three dimensions, individual dimension, normative dimension and worldly dimension. Table 4 shows the differences between man and women respondents.

Table 4. Attainable values through working

\begin{tabular}{|l|l|c|c|c|c|c|c|}
\hline & \multicolumn{1}{|c|}{ Work Value } & Man & & Women & & All & \\
\hline \multirow{4}{*}{ Individual } & To gain information & 5.97 & & 7.46 & & 6.72 & \\
Dimension & To gain freedom & 9.73 & & 11.24 & & 10.49 & \\
& To have an active life & 9.04 & 8.67 & 7.72 & 9.69 & 8.38 & 9.18 \\
& To keep busy & 11.6 & & 15.06 & & 13.33 & \\
& To find meaning in life & 6.99 & & 6.96 & & 6.98 & \\
\hline \multirow{3}{*}{ Normative } & To fulfill religious duty & 8.02 & & 6.67 & & 7.35 & \\
Dimension & To contribute society & 7.17 & \multirow{2}{*}{7.42} & 9.27 & \multirow{2}{*}{7.13} & 8.22 & \\
& To create order & 7.51 & & 6.96 & & 7.24 & \\
& To avoid negativity & 6.99 & & 5.6 & & 6.29 & \\
\hline \multirow{2}{*}{ Worldly } & To make a living & 8.36 & & 5.94 & & 7.15 & \\
Dimension & To gain status & 11.77 & 8.99 & 11.52 & 8.56 & 11.64 & 8.34 \\
& To enjoy life & 6.85 & & 5.6 & & 6.23 & \\
\hline
\end{tabular}

\section{DISCUSSION AND CONCUSSION}

Based on common overview, work is part of human life to earn money, to defend the life and to fulfill family welfare (Anoraga, 2006). It means that working is an activity which motivated by economic needs. The research result shows that Javanese employees work not only for economic value but for another reason which highest than it; that are to do something meaningful, to carry out religious teaching, to gain self-actualization, to apply knowledge and to add new insight. One of the definition is founded different from other is 'work as activities to carry out religious teaching'. This is because Javanese people believe in God as the central of the world (Damami, 2002). The God provides everything for human being. The implications of this believe is people must serve the God and obey the God rules. Javanese have faith that God has set the fortune for each person therefore people do work to serve the God and they will receive fortune (Soesilo, 2006).

Javanese employees believe that work is not only to fulfill need of life but also achieving life satisfaction and meaning of life. Sibagariang (2011) said, as far as they enjoying the work and doing it as good as possible then they will get fortune from other sources even though their main work is not able to give a lot of money. They believe that God bless people who always be grateful (Soesilo, 2006). The God will grants goodness of life for grateful people in variation ways, a lot of money, health or life satisfaction (Sibagariang, 2011). 


\section{How Do Javaneesee Employees Perceive About Their Job ? : A Study of Javanese Employees Work Value}

Javanese employees believe, they will enjoy working if they meet the requirements of work, that are discipline, loyalty, honesty, responsibility, totality, good relationship with co-workers and enthusiasm. The value of good relationship with co-workers arises because Javanese people are known as people who try to maintain good relation with others. This refers to Javanese cultural value which reflects the nature of cooperation as mutual cooperation, mutual help, feeling the same boat in joy and sorrow. Therefore, the implementation of Javanese phrases "Saiyek saeko praya” that means working together to achieve a common goal (Herusatoto, 2003).

Javanese people live in collective culture so they realize that have good relation important. This situation makes them not able to show assertiveness (Margareth, Kusrestuwardhani, and Alkadri, 2002). They have high tolerance in disagreements in order to maintain good relation with others (Christina and Adrian, 2004).

Finding about the most attainable value through working shows that Javanese employees are dominated by individual dimension, wordly dimension and then normative dimension. The results indicate that 'to keep busy' and 'to gain status' are dominant than another. Women employees are high in individual dimension, meanwhile the men's are high in wordly dimension.

These results contribute to understand Javanese culture. Furthermore, it is needed to do more measurement and involve many variables to get comprehensive understanding about the affect of Javanese work value to many areas of management.

\section{REFERENCES}

Abboushi, S. (1990). The impact of individual variable on the work values of Palestinian Arabs. International Study of Management and Organizatios, 20, pp. 53-68.

Anoraga, Panji. (2006). Psikologi Kerja. Jakarta : Rineka Cipta

Ben-Shem, I. and Avi-Itzhak, T.S. (1991). On work values and career choice in freshmen studies : The case of helping vs. other proffesions. Journal of Vocational Behavior, 39, pp. 369379.

Christina S. Handayani and Ardhian Novianto. (2004). Kuasa wanita Jawa. PT. LKIS : Yogyakarta

Damami, Mohammad. (2002). Makna agama dalam masyarakat Jawa. Lesfi.

Dose, J.J. (1997). Work values : An integrative framework and illustrative application to organization socialization. Journal of Occupational and Organizational Psychology, 70, pp. 219-240.

Graham, J.L., Mintu, A.T. and Rodgers, W. (1994). Explorations of negotiation behaviors in ten foreign cultures using a model developed in the United States. Management Science, 40 (1), pp 72-95.

Hofstede, G. (1980). Motivation, leadership and organizations: Do Americans theories apply abroad ?. Organizational Dynamics, 9 (1), pp.42-63). 


\section{How Do Javaneesee Employees Perceive About Their Job ? : A Study of Javanese Employees Work Value}

Hoppe, M.H. (1990). A comparative study of country elites : International differences in workrelated values and learning and their implications for management training and development. Unpublished doctoral dissertation, University of North Carolina at Chapel Hill.

Hoppe, M.H. (1993). The effects of national culture on the theory of practice and managing $R \& D$ professionals abroad. $R \& D$ Management, 23 (4), pp 313-325.

Herusatoto, Budiono. (2003). Simbolisme dalam budaya Jawa. Yogyakarta : Hanindita Graha Widia.

Kim, Uichol dan Berry, W.J. (1993). Indigenous psychologies research and experience in cultural context. Sage Publications.

Kim, K.I., Park, Hun-Joon and Suzuki, N. (1990). Reward allocations in the United States, Japan and Korea : A comparison of individualistic and collectivistic cultures. Academy of Management Journal, 33 (1), pp. 188-198.

Li, W., Liu, X. and Wan, W. (2008). Demographic effects of work values and their management implications. Journal of Business Ethics, 81, pp. 875-885.

Margareth P. Gautama, Kusrestuwardhani, and Alkadri. (2003). Budaya Jawa dan masyarakat modern. Pusat Pengkajian Kebijakan Teknologi Pengembangan Wilayah, Badan Pengkajian dan Penerapan Teknologi.

Markus, R.H., and Kitayama, S. (1991). Culture and the self : Implications for cognition, emotion, and motivation. Psychological Review, 98, 2, pp.224-253.

Meglino, B.M. and Ravlin, E.C. (1998). Individual Values in Organizations : Concepts, Controversies and Research. Journal of Management, 24 (3), 351-390.

Meiyanto, Sito. And Santhoso, H.F. (1999). Nilai-nilai kerja dan komitmen organisasi : sebuah studi dalam konteks pekerja Indonesia. Jurnal Psikologi. Universitas Gadjah Mada,1, pp. 29-40.

Mitra, A.D., Jenkins, D.J., and Gupta, N. (1992). A meta analytic review of the relationship between absence and turnover. Journal of Applied Psychology,77, pp.897-889.

Primasari, A. and Yuniarti, K.W. (2012). What make teenagers happy ? An exploratory study using indigenous psychology approach. International Journal of Research Studies in Psychology, 1 / 2, pp.53-61.

Rokeach, Milton. (1973). The Nature of Human Values. New York : Free Press.

Ronen, S., Shenkar, O. (1985). Clustering countries on attitudinal dimensions : A review and synthesis. The Academy of Management Review, 10 (3), pp. 435-454.

Sibagariang, Eva., (2011). Nilai kerja abdi dalem Keraton Ngayojokarto Hadiningrat. Unpublished Thesis, Universitas Negeri Semarang.

Soesilo. (2006). Kejawen: philosofi \& perilaku. Yayasan Yusula.

Sulastiana, Marina. (2008). Telaah filsafat dalam kajian pengaruh nilai-nilai kerja dan motivasi kerja terhadap komitmen organisasi dan kualitas pelayanan edukatif. Jurnal Fakultas Psikologi Unpad. 
Super, D.E. (1973). The work values inventory in Zytowski, D.G. (ed.), Contemporary approaches to interest measurement. Minneapolis, MN : University of Minnesota Press, pp. 189-205.

Ucanok, Basak. (2008). The effect of work value, work-value congruence, and work centrality on organizational citizenship behavior. World Academy of Science, Engineering, and Technology, 46.

Zedeck, S. (1997). Commentary on diversity and work-family values. New Perspectives on International Industrial/Organizational Psychology. 319-332, New Lexington Press. San Fransisco.

Varner, I., and Beamer, L. (1995). Intercultural communication in the global workplace. Chicago : Irwin.

Woo, Boyun.2009. Culture effects on work attitude \& behavior the case of american and korean fitness employees. Desertation The Ohio State University 